\title{
Tantangan Guru dan Orang Tua dalam Kegiatan Belajar Dari Rumah Anak Usia Dini pada Masa Pandemi Covid-19
}

\author{
Isti Yuli Astuti ${ }^{1 凶}{ }^{\otimes}$ Harun $^{2}$ \\ Pendidikan Anak Usia Dini, Universitas Negeri Yogyakarta \\ DOI: $10.31004 /$ obsesi.v5i2.808
}

\begin{abstract}
Abstrak
Tujuan dari penelitian ini untuk mendeskripsikan berbagai tantangan yang dihadapi oleh guru dan orang tua dalam mendampingi kegiatan Belajar Dari Rumah (BDR) anak usia 4-6 tahun pada masa pandemi Covid-19. Penelitian ini dianalisis menggunakan metode deskriptif kualitatif dengan pendekatan studi kasus, melibatkan 6 subjek terdiri dari 3 guru dan 3 orang tua anak usia 4-6 tahun di Kabupaten Bantul. Pengumpulan data dalam penelitian ini menggunakan teknik wawancara dan dokumentasi. Berdasarkan hasil penelitian yang dilakukan, menunjukkan bahwa dari kegiatan belajar dari rumah guru mendapatkan beberapa tantangan, diantaranya guru harus menyiapkan kegiatan yang menarik dan menyesuaikan bahan kegiatan di sekitar anak, stand by memantau kegiatan yang dilakukan anak melalui whatsapp, dan penilaian hanya melalui video/foto. Tantangan yang dihadapi orang tua dalam mendampingi anak belajar diantaranya harus mengetahui dan mengatasi mood belajar anak, mengajak anak melakukan kegiatan belajar dengan suasana yang menyenangkan, serta dapat membagi waktu antara pekerjaan dan mendampingi anak belajar. Kata Kunci: Tantangan guru dan orangtua; belajar dari rumah; anak usia dini, covid-19
\end{abstract}

\begin{abstract}
The purpose of this study was to describe the various challenges faced by teachers and parents in accompanying Belajar Dari Rumah (BDR) for children aged 4-6 years during the Covid-19 pandemic. This study was analyzed using a qualitative descriptive method with a case study approach, involving 6 The subjects consisted of 3 teachers and 3 parents of children aged 4-6 years in Bantul Regency. Data collection in this study used interview and documentation techniques. must prepare interesting activities and adjust the material for activities around the child, stand by monitoring activities carried out by children through WhatsApp, and assessments only through videos / photos. Challenges faced by parents in assisting children in learning include knowing and overcoming the child's learning mood, inviting children do learning activities with an enjoyable atmosphere, and can divide time between work and accompanying children to study.

Keywords: Challenges for teachers and parents; learning from home; early childhood, covid-19.
\end{abstract}

Copyright (c) 2020 Isti Yuli Astuti, Harun

$\triangle$ Corresponding author :

Email Address : istiyuli11@gmail.com ( Yogyakarta, Indonesia )

Received 12 October 2020, Accepted 7 November 2020, Published 28 November 2020 


\section{PENDAHULUAN}

Virus corona atau biasa disebut dengan Covid-19 (Corona Virus Desease) merupakan virus yang pertama kali ditemukan di kota Wuhan, China pada akhir tahun 2019 (Lee, 2020). Jumlah pasien akibat Covid-19 semakin bertambah setiap harinya, baik di dalam negeri maupun di luar negeri. Tercatat jumlah kasus Virus Corona (Covid-19) di seluruh dunia mencapai 28,6 juta kasus, dengan pasien terbanyak 6,4 juta kasus dari Amerika Serikat. Kasus Covid-19 di Indonesia mencapai 214 ribu dengan tingkat kematian yang tinggi di Asia Pasifik dan Asia Tenggara (Kurnia, 2020).

Penambahan pasien akibat virus corona di berbagai penjuru dunia membuat aktivitas kegiatan di seluruh dunia menjadi kacau. Mulai dari aktivitas ekonomi, sosial, hingga aktivitas di bidang pendidikan menjadi terbatas bahkan hingga terjadi penghentian aktivitas kegiatan. Dunia telah berubah secara dramatis sejak dimulainya pandemi COVID-19 dan ini telah terjadi termasuk dalam aktivitas pendidikan di semua tingkatan (Mamun et al., 2020).

Pemerintah Indonesia mengeluarkan kebijakan untuk melakukan social distancing dan memberlakukan PSBB (Pembatasan Sosial Berskala Besar) di bebarapa kota besar di Indonesia pada bulan Maret 2020 guna memutus mata rantai Covid-19 (Azanella, 2020). Akibat dari pembatasan sosial tersebut berdampak terhadap aktivitas yang berjalan selama ini, salah satunya pada kegiatan pembelajaran di sekolah. Pemerintah mengeluarkan kebijakan Belajar Dari Rumah (BDR) kepada seluruh pelajar yang ada di Indonesia, mulai dari tingkat Pendidikan Anak Usia Dini hingga perguruan tinggi (Menteri Pendidikan dan Kebudayaan Republik Indonesia, 2020).

Kebijakan Belajar Dari Rumah (BDR) ditujukan kepada semua jenjang pendidikan, mulai dari Taman Kanak-kanak (TK) hingga perguruan tinggi. Kegiatan BDR dilakukan guna memutus rantai Covid-19 dalam bidang pendidikan. Sehubungan dengan kegiatan BDR, guru tetap memantau kegiatan yang dilakukan oleh siswa. Kegiatan BDR dilakukan dengan memanfaatkan kemajuan teknologi masa kini, yaitu gadget. Gadget merupakan salah satu bentuk nyata dari berkembangnya ipteks pada masa kini (Pebriana, 2017). Adanya gadget dapat memudahkan interaksi antara guru dan murid dalam melakukan kegiatan BDR melalui pembelajaran daring dari rumah. Interaksi guru, orangtua dan murid biasanya dilakukan melalui grup whatsapp, guru bisa membagikan materi maupun menerima laporan kegiatan belajar anak di rumah melalui grup whatsapp (Hutami \& Nugraheni, 2020).

Kegiatan BDR di TK tidak hanya melibatkan peran guru dan siswa, namun juga melibatkan peran orang tua di dalamnya. Peran orang tua dalam kegiatan BDR pada anak TK sangat penting karena orangtua sebagai pengganti guru yang mendampingi anak dalam kegiatan BDR (Wardani \& Ayriza, 2020). Guru dan orang tua bekerja sama dalam melakukan kegiatan BDR, guru sebagai perencana pembelajaran yang akan dilakukan dalam kegiatan DBR serta penilai hasil pembelajaran anak di rumah (Hewi \& Asnawati, 2020). Peran orang tua dalam kegiatan BDR yaitu mendampingi dan memotivasi anak selama melakukan kegiatan di rumah. Kolaborasi antara guru dengan orang tua sangatlah penting karena pada anak usia dini masih belum dapat menerima instruksi guru dengan sangat jelas karena kurangnya pengalaman dan pengetahuan proses pelaksanaan daring pada anak usia dini (Hakim, 2020). Sekolah dan orang tua dalam menghadapi kegiatan pembelajaran pada masa pandemi Covid-19 harus memiliki persiapan yang matang, dengan tujuan kegiatan pembelajaran berjalan lancar dan efektif (Ayuni et al., 2021).

Kondisi yang terjadi pada saat pandemi Covid-19 dengan kegiatan pembelajaran menggunakan kegiatan Belajar Dari Rumah (BDR) merupakan hal baru bagi guru, siswa, maupun orangtua khususnya di Taman Kanak-kanak. Guru sebagai pendidik dituntut dalam memberikan kegiatan anak selama di rumah menggunakan berbagai kegiatan yang disesuaikan usia dan aspek perkembangan anak. Selain itu, kegiatan juga tetap menggunakan kegiatan yang disesuaikan dengan kurikulum 2013, yaitu menggunakan pembelajaran tematik dengan pendekatan saintifik. Pendekatan saintifik bertujuan untuk memberikan pemahaman kepada anak untuk mengenal dan memahami berbagai materi menggunakan 
pendekatan ilmiah. Melalui pendekatan saintifik dijelaskan bahwa informasi dapat berasal dari mana saja, kapan saja, tidak hanya bergantung pada informasi yang disampaikan oleh guru (Suryana, 2017). Selain dari guru, orang tua sebagai pendamping kegiatan anak di rumah juga dituntut dalam penyampaian informasi kepada anak dan penyediaan fasilitas lingkungan belajar anak di rumah yang sesuai dengan rancangan kegiatan guru di sekolah.

Pelaksanaan kegiatan BDR di Taman Kanak-Kanak tentu saja bagi guru, siswa maupun orang tua memiliki tantangannya masing-masing. Tantangan kegiatan BDR di TK sangat dirasakan oleh guru maupun orang tua sebagai pendamping dalam kegiatan anak, serta mengingat pendidikan anak usia dini menjadi salah satu faktor penting bagi seluruh aspek perkembangan anak agar berkembang secara optimal untuk menempuh jenjang pendidikan selanjutnya (Satrianingrum \& Prasetyo, 2020). Selain itu, tantangan lain berkaitan pada terbatasnya kemampuan dalam penguasaan gadget oleh guru dan orang tua, perencanaan kegiatan yang dilakukan guru yang disesuaikan dengan bahan-bahan yang ada di sekitar anak, orang tua harus mengatasi kesulitan anak dalam melakukan kegiatan, pendampingan kegiatan belajar anak oleh orang tua yang juga bekerja, dan sebagainya. Bagi beberapa orang tua merasa lebih terhubung dengan anak melalui tugas sekolah, namun beberapa orang tua merasa mendapatkan beban tambahan harus mendampingi anak dalam kegiatan sekolah (Selwyn et al., 2011).

Berdasarkan beberapa hal di atas, kajian dalam penelitian ini sangat penting dilakukan guna mengetahui berbagai tantangan dan solusi untuk mengatasi masalah yang dihadapi oleh guru dan orang tua dalam mendampingi kegiatan BDR pada anak usia 4-6 tahun selama masa pandemi Covid-19.

\section{METODOLOGI}

Penelitian ini menggunakan metode penelitian kualitatif deskriptif dengan pendekatan studi kasus (case study). Pendekatan studi kasus merupakan bagian dari metode kualitatif untuk mendalami suatu kasus tertentu secara lebih mendalam dengan melibatkan pengumpulan sumber informasi (Raco, 2018). Penelitian ini dilatarbelakangi oleh fenomena yang terjadi terhadap kegiatan belajar anak TK yang dilakukan mengikuti kebijakan dari pemerintah, yaitu Belajar Dari Rumah (BDR). Selain melibatkan guru dan anak, kegiatan BDR juga melibatkan orangtua sebagai pendamping kegiatan belajar anak. oleh sebab itu, penelitian ini dilakukan untuk mengetahui berbagai tantangan guru dan orangtua dalam mendampingi kegiatan BDR pada anak usia 4-6 tahun selama masa pandemi Covid-19. Subjek dalam penelitian ini melibatkan 3 orang guru TK (YA, LP, IR) dari sekolah yang melaksanakan kegiatan BDR yang dipilih dari 3 TK yang berbeda dan 3 orang tua yang memiliki anak usia 4-6 tahun sekolah di TK (YN, LS, RN), terdiri dari orang tua yang bekerja sebagai ibu rumah tangga, pedagang, dan Pegawai Negeri Sipil (PNS) di Kabupaten Bantul.

Teknik pengumpulan data yang digunakan dalam penelitian ini menggunakan teknik wawancara dan dokumentasi. Wawancara dilakukan secara mendalam untuk mengetahui berbagai tantangan yang dihadapi oleh guru dan orang tua yang mendampingi anak usia 4-6 tahun selama kegiatan BDR. Dokumentasi sebagai bukti pendukung data yang diperoleh selama penelitian berlangsung berupa lampiran data yang berisi identitas guru, siswa, dan orang tua siswa, Rencana Pelaksanaan Pembelajaran Mingguan (RPPM), serta foto maupun video pada saat kegiatan BDR berlangsung. Pengumpulan data melalui wawancara dan dokumentasi dilakukan oleh peneliti di masing-masing sekolah dengan guru dan orang tua siswa yang dijadikan narasumber terpilih. Proses analisis data pada penelitian ini melalui tiga 
tahapan yaitu reduksi data, display data, serta kesimpulan dan verifikasi data. Penelitian ini dilakukan pada bulan Agustus 2020.

Berikut ini adalah alur penelitian yang akan dilakukan oleh peneliti:

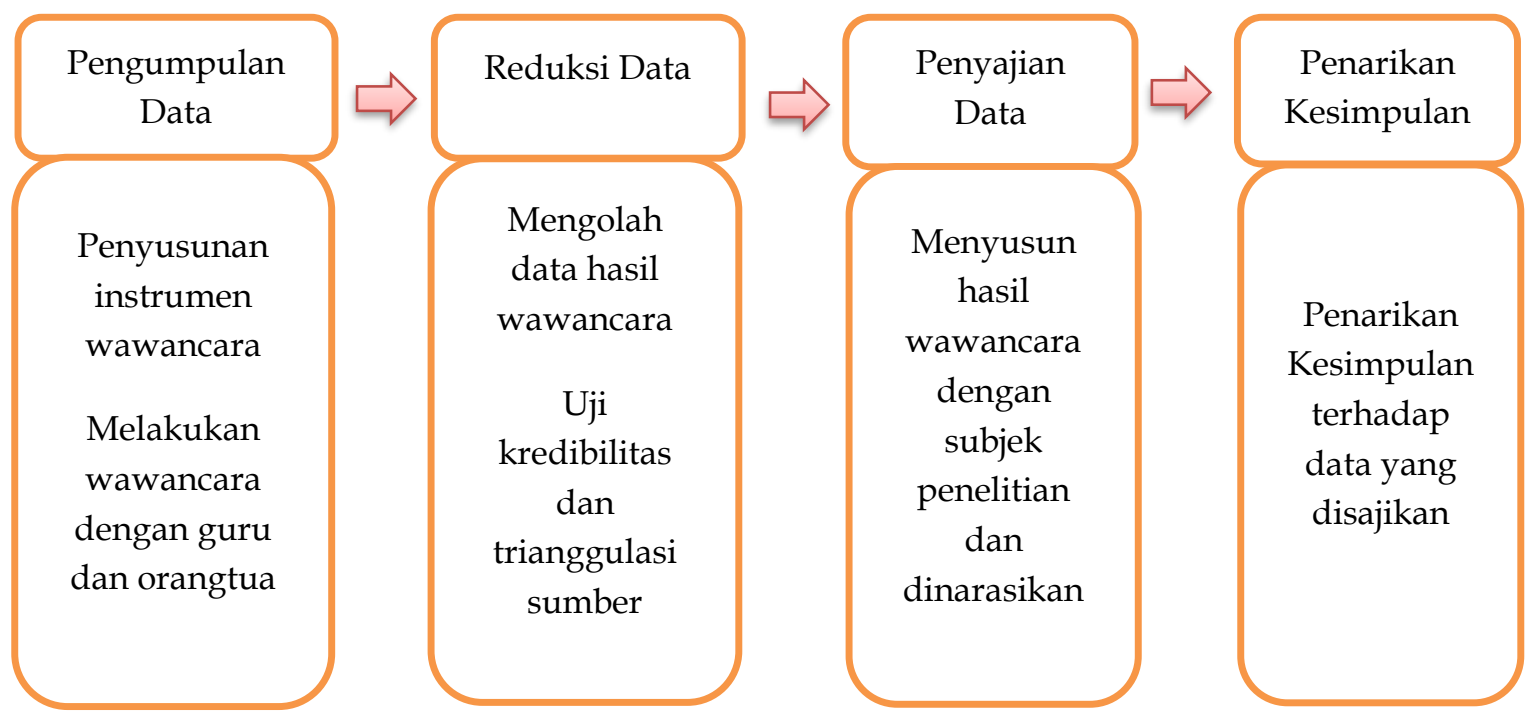

\section{Gambar 1. Alur Penelitian}

\section{HASIL DAN PEMBAHASAN}

Pandemi Covid-19 sangat berpengaruh pada aktivitas kegiatan pembelajaran di sekolah. Peran sekolah sebagai tempat untuk belajar, di masa pandemi Covid-19 digantikan rumah sebagai tempat belajar anak-anak untuk melakukan kegiatan belajar. Namun, peran guru tetaplah sangat diperlukan walaupun kegiatan belajar dilakukan di rumah. Guru dan orangtua bekerjasama dalam pelaksanaan kegiatan belajar anak di rumah, walaupun peran guru sebagai fasilitator dalam mendampingi anak belajar digantikan oleh orang tua di rumah. Guru sebagai fasilitator dalam memberikan materi dan bahan kepada anak, sedangkan orang tua yang mendampingi dan mengawasi anak dalam melakukan kegiatan dari guru di rumah. Sebagaimana yang dipaparkan oleh guru yang berperan dalam memberikan materi dan bahan pembelajaran kepada anak di bawah ini.

...walaupun kegiatan anak dilakukan di rumah, namun guru tetap membuat rencana kegiatan anak selama satu minggu... (kutipan wawancara dengan guru $Y A$ )

...kegiatan anak selama satu minggu tersusun dalam Rencana Pelaksanaan Pembelajaran Mingguan (RPPM) yang telah disusun guru, kemudian orangtua mengambil materi dan sebagian bahan kegiatan di sekolah setiap satu minggu sekali... (kutipan wawancara dengan guru IR)

Materi dan bahan yang digunakan anak dalam kegiatan belajar di rumah disusun oleh guru melalui Rencana Pelaksanaan Pembelajaran Mingguan (RPPM). Rencana Pelaksanaan Pembelajaran Mingguan (RPPM) merupakan rencana kegiatan pembelajaran yang akan dilakukan selama satu minggu (Ali Nugraha, 2018). Selama masa pandemi Covid-19, kegiatan pembelajaran anak di Taman Kanak-kanak menggunakan Rencana Pelaksanaan Pembelajaran Mingguan (RPPM) yang dirancang lebih sederhana terdiri dari enam macam kegiatan disesuaikan dengan enam aspek perkembangan anak, serta kegiatan pembelajaran dilakukan satu hari satu kegiatan dengan pendampingan orang tua di rumah (Hasbi, Wahyuni, et al., 2020). Sebelum terjadinya pandemi Covid-19, perencanaan pembelajaran menggunakan Rencana Pelaksanaan Pembelajaran Harian (RPPH) yaitu perencanaan yang akan memandu jalannya kegiatan dalam satu hari di Taman Kanak-kanak (TK) yang disusun berdasarkan 
Rencana Pelaksanaan Pembelajaran Mingguan (RPPM). Komponen RPPH biasanya memuat isian identitas lembaga, tema/subtema, kelompok usia, alokasi waktu, kegiatan belajar (pembuka, inti, penutup), indikator pencapaian pembelajaran, media dan sumber belajar yang digunakan (Ali Nugraha, 2018).

Kegiatan pembelajaran selama pandemi Covid-19 yang dilakukan di rumah secara daring tentu saja mengalami berbagai tantangan, baik bagi guru maupun orangtua. Guru sebagai pendidik menghadapi berbagai tantangan dalam perencanaan, pelaksanan dan pemantauan kegiatan pembelajaran anak TK. Orangtua menghadapi berbagai tantangan dalam mendampingi anak melakukan kegiatan pembelajaran di rumah maupun dalam membagi waktu antara kegiatan mendampingi kegiatan belajar anak dan mengerjakan pekerjaannya. Tantangan yang dialami guru dan orangtua anak usia 4-6 tahun akan dibahas lebih spesifik sesuai dengan hasil wawancara yang telah dilakukan dengan guru dan orangtua yang dijabarkan sebagai berikut ini.

\section{Persiapan Perencanaan Kegiatan Pembelajaran yang dilakukan Oleh Guru}

Menghadapi kegiatan pembelajaran dari rumah, tentu saja menjadi tantangan bagi guru. Kegiatan yang diberikan guru harus tetap memperhatikan tingkat kemampuan anak sesuai dengan tingkat usia anak. Suasana atau situasi yang berbeda di sekolah dan rumah tentu saja akan berpengaruh terhadap perasaan dalam diri anak untuk melakukan kegiatan pembelajaran. Oleh sebab itu, perencanaan kegiatan yang disusun oleh guru harus lebih menarik bagi anak dan juga guru harus memperhatikan bahan atau media pendukung dalam kegiatan belajar anak selama di rumah. Sebagaimana yang dipaparkan oleh beberapa guru TK di bawah ini.

...membuat perencanaan menggunakan APE yang ada di rumah dengan kegiatan semenarik mungkin... (kutipan wawancara dengan guru LP)

...supaya anak kreatif, kadang kita membebaskan anak untuk menggunakan benda-benda yang ada di rumah mereka... (kutipan wawancara guru YA)

...kegiatan yang diberikan kepada siswa haruslah menarik, sehingga akan menumbuhkan minat anak untuk mengerjakan kegiatan belajar yang diberikan... (kutipan wawancara dengan guru IR)

Perencanaan kegiatan pembelajaran merupakan hal yang penting untuk mengarahkan kegiatan pembelajaran untuk mencapai tujuan yang diinginkan (Apriyanti, 2017). Selain itu, perencanaan kegiatan harus disesuaikan antara tema kegiatan dengan bahan atau media pembelajaran yang ada di rumah maupun lingkungan tempat tinggal, karena bahan ataupun media yang digunakan akan berpengaruh terhadap kegiatan belajar anak. Media pembelajaran digunakan untuk membawa informasi berupa materi ajar dari guru kepada murid sehingga murid menjadi lebih tertarik untuk mengikuti kegiatan pembelajaran (Sujarwo, 2012). Media pembelajaran dapat berupa media visual, media audio, maupun media audio-visual. Media atau bahan belajar yang ada di rumah biasanya bisa menggunakan gadget, bahan alam yang berasal dari lingkungan sekitar anak, barang bekas seperti tutup botol, botol plastik bekas, gelas plastik, tali, kardus, dan lain-lain (Pendidikan et al., 2020).

Berbagai kegiatan dan penggunaan bahan pembelajaran menarik yang dirancang guru akan mendukung berlangsungnya kegiatan pembelajaran yang disukai maupun diminati oleh anak. Guru menciptakan banyak kegiatan menarik yang dapat membangkitkan rasa ingin tahu, memotivasi berpikir kritis dan kreatif pada anak (Nugraha et al., 2018a). Selain perencanaan kegiatan pembelajaran yang menarik, kegiatan pembelajaran di rumah tetap menggunakan pembelajaran tematik dengan pendekatan saintifik. Pembelajaran tematik di TK disesuaikan dengan tema yang ada di kurikulum sekolah. Tema yang dipilih juga disesuaikan dengan lingkungan sekitar anak, sehingga kegiatan dapat secara langsung dilakukan menggunakan pendekatan saintifik berdasarkan pedoman dari kurikulum 2013. Pendekatan saintifik digunakan untuk membangun cara berpikir anak melalui proses mengamati, menanya, mengumpulkan informasi, menalar dan mengkomunikasikan hasil 
pemikirannya, serta pendekatan saintifik akan menambah pengalaman anak (Nugraha et al., 2018a). Kegiatan pembelajaran menggunakan pendekatan saintifik yang disesuaikan dengan tema pembelajaran dengan bahan pembelajaran penunjang yang nyata akan membuat anak lebih tertarik dalam melakukan kegiatan pembelajaran di rumah.

\section{Pelaksanaan Pemantauan Pembelajaran dan Penilaian Pembelajaran yang dilakukan Oleh Guru}

Pembelajaran daring tentu saja berpengaruh pada pencapaian perkembangan anak usia dini di Taman Kanak-kanak (Wulandari \& Purwanta, 2021). Anak melakukan kegiatan belajar selama pandemi Covid-19 di rumah bersama orang tua. Hal tersebut bukanlah hal yang seharusnya tidak menjadi masalah, karena dari orang tua atau keluarga anak mendapatkan pendidikan pertamanya (Lilawati, 2020). Selama kegiatan belajar berlangsung, orang tua berperan dalam membimbing dan mendampingi anak belajar sebagai pengganti guru di sekolah. Selain menjadi pembimbing dan pendamping belajar anak, orang tua juga diminta untuk merekam video atau memfoto setiap kegiatan belajar yang dilakukan anak. Kemudian, hasil rekaman video ataupun foto dikirimkan kepada guru sebagai bukti anak telah melaksanakan kegiatan belajar di rumah. Sebagaimana yang dipaparkan oleh beberapa guru di bawah ini terkait dengan pemantauan dan penilaian pembelajaran oleh guru.

...harus meluangkan waktu 24 jam untuk memantau kegiatan anak, terkadang orangtua mengirimkan foto/video pada malam hari... (kutipan wawancara guru $Y A$ )

...memantau kegiatan anak setiap saat melalui video call, sesuai waktu senggang orangtua dalam mendampingi anak belajar maupun pada saat anak sudah memiliki minat untuk belajar... (kutipan wawancara guru LP)

...terkadang orangtua lupa untuk mengirimkan foto/video dokumentasi anak dalam melakukan kegiatan anak belajar, sehingga harus mengingatkan orangtua... (kutipan wawancara guru IR)

Pada masa pandemi Covid-19 dengan kegiatan belajar dilakukan di rumah secara daring, guru tetap wajib melakukan penilaian di setiap kegiatan yang anak lakukan di rumah (Hasbi, Wardhani, et al., 2020). Guru harus meluangkan lebih banyak waktu untuk memantau kegiatan maupun hasil dari kegiatan siswa, mengingat pekerjaan orang tua siswa bermacammacam dan mencari waktu senggang untuk mendampingi anak melakukan kegiatan belajar maupun mengirimkan atau melaporkan kegiatan belajar anak selama di rumah. Melalui video dan foto yang dikirimkan oleh orang tua maupun melalui video call langsung dengan anak, guru dapat melakukan penilaian pada anak. Penilaian terhadap anak terkait dengan kegiatan belajar anak sangat penting dilakukan. Hal tersebut dilakukan untuk memantau hasil pencapaian perkembangan anak selama mengikuti kegiatan yang telah diberikan oleh guru. Penilaian dan pelaporan perkembangan anak harus dilakukan oleh guru yang bersifat sangat penting. Melalui penilaian dan pelaporan yang dilakukan oleh guru, dapat diketahui tingkat pencapaian perkembangan yang telah dicapai oleh anak (Maryani, 2020).

Kegiatan belajar di PAUD menggunakan penilaian otentik. Penilaian otentik adalah penilaian terhadap proses dan hasil belajar untuk mengukur tingkat pencapaian kompetensi anak, meliputi kompetensi sikap (spiritual dan sosial), pengetahuan, dan keterampilan berdasarkan fakta yang sesungguhnya (Nugraha et al., 2018b). Pada kegiatan belajar dari rumah, penilaian dilakukan oleh guru menggunakan teknik observasi melalui foto ataupun video yang dikirimkan oleh orangtua dan melalui hasil karya yang dibuat oleh anak. Beberapa guru mengalami kendala dan tantangan terkait dengan penerimaan video atau pun foto yang kurang jelas dan tidak menyeluruh. Sebagaimana yang dipaparkan oleh beberapa guru sebagai berikut ini.

...beberapa orangtua mengirimkan foto pada awal dan akhir anak melakukan kegiatan, maupun orangtua hanya mendokumentasi video anak melakukan kegiatan tidak penuh. Sehingga pengamatan guru hanya terbatas... (kutipan wawancara guru YA) 
...penilaian guru terhadap kegiatan anak terbatas, hanya melalui video dan foto, bahkan terkadang orangtua lupa untuk mendokumentasikan... (kutipan wawancara guru IR)

Apabila teknik observasi yang dilakukan guru melalui video maupun foto kurang mendukung atau memadai dalam kegiatan penilaian oleh guru, maka guru biasanya juga menggunakan teknik wawancara kepada orangtua. Teknik wawancara ini bertujuan memperoleh informasi yang mendalam terkait dengan kegiatan belajar anak di rumah, sehingga dapat diketahui secara detail pencapaian perkembangan yang telah dicapai anak. Hasil dari pengumpulan data berupa penilaian terhadap anak, akan diolah untuk mengetahui setiap perkembangan pencapaian anak di setiap kegiatan belajar.

\section{Pelaksanaan Kegiatan Belajar Dari Rumah (BDR) Pendampingan Oleh Orang Tua di Rumah}

Peran guru yang digantikan oleh orang tua di rumah dalam kegiatan belajar, tentu saja menjadikan tantangan baru bagi orang tua. Orang tua dituntut untuk memahami materi yang diberikan guru kemudian disampaikan kepada anak. Namun, masalah yang terjadi bukanlah soal pemahaman materi pada orang tua yang diberikan oleh guru, biasanya orang tua mengalami kesulitan dalam pelaksanaan pembelajaran dengan anak. Kesulitan yang dialami biasanya berasal dari dalam diri anak yang sulit untuk diajak dalam melaksanakan kegiatan belajar bersama orangtua di rumah. Kesulitan dalam kegiatan pembelajaran tersebut akan berpengaruh pada tujuan pendidikan yang akan dicapai. Tujuan pendidikan akan tercapai apabila kegiatan pembelajaran dapat berlangsung dengan baik dan maksimal (Fadlillah, 2014). Beberapa tantangan dan kesulitan yang harus dilalui oleh beberapa orang tua dalam pendampingan kegiatan belajar anak selama di rumah dipaparkan sebagai berikut ini.

$Y N, L S)$.

...anak sangat sulit untuk diajak melakukan kegiatan belajar di rumah... (kutipan wawancara ibu RN,

Suasana belajar di sekolah dan di rumah tentu saja sangat berbeda. Suasana belajar di sekolah lebih mendukung dibandingkan suasana belajar di rumah. Hal yang mendukung suasana belajar di sekolah diantaranya kegiatan belajar yang dilakukan bersama guru yang memiliki pengalaman dalam mendampingi anak melakukan kegiatan, teman-teman sebaya anak di sekolah, fasilitas Alat Peraga Edukatif (APE) yang mendukung, dan lain-lain. Suasana lingkungan sekolah tentu saja membuat anak lebih termotivasi untuk melakukan kegiatan belajar. Motivasi belajar adalah kekuatan mental bagi anak yang mendorong terjadinya proses pembelajaran. Motivasi yang dimiliki peserta didik bersifat fluktuatif artinya motivasi peserta didik terjadi naik turun hal belajar (Rozana et al., 2020). Sebagaimana yang dipaparkan oleh beberapa orang tua dalam mendampingi anak melakukan kegiatan belajar dari rumah berikut ini.

...harus mengetahui mood anak, apakah sudah mau belajar atau belum... kegiatan belajar kami lakukan layaknya kami sedang bermain dengan anak... (kutipan wawancara ibu RN)

(kutipan wawancara ibu RN)

...anak mau melakukan kegiatan belajar ketika kakaknya juga sedang mengerjakan tugas sekolah... membuat perlombaan dalam menyelesaikan kegiatan belajar... (kutipan wawancara ibu YN)

...salah satu cara membangun mood belajar anak adalah dengan memberikan hadiah kepada anak... (kutipan wawancara ibu LS)

Motivasi dalam diri anak yang bersifat fluktuatif tentu saja akan berpengaruh pada kegiatan belajar dan hasil belajar anak. Meskipun motivasi belajar anak di rumah lebih rendah dibandingkan motivasi belajar anak di sekolah, namun orang tua dapat menciptakan suasana yang mendukung bagi anak untuk melakukan kegiatan belajar. Orang tua dapat mengajak anak belajar dengan suasana yang menyenangkan yang dapat dilakukan salah satunya menggunakan metode bermain. Menurut Piaget dalam teori kognitif, dijelaskan bahwa 
kegiatan bermain dapat membangun dan mengembangkan pengetahuan pada anak (Fadillah, 2019). Sehingga kegiatan bermain selain menyenangkan, metode bermain dapat menumbuhkan minat dan motivasi anak dalam melakukan kegiatan belajar.

Selain metode kegiatan belajar yang menyenangkan menggunakan metode bermain, orang tua dapat menumbuhkan minat belajar anak menggunakan hadiah atau reward sebagai bentuk penghargaan bagi anak yang telah melaksanakan kegiatan belajar di rumah. Hadiah atau reward adalah sebuah penghargaan yang diberikan kepada seseorang yang telah melakukan suatu pencapaian berupa prestasi, perilaku baik, rajin, tekun, dan lain-lain (Puspitasari, 2016). Reward digunakan oleh guru PAUD untuk memotivasi anak dalam melakukan kegiatan belajar atas pencapaian maupun perilaku baik anak. Guru memberikan reward dapat berupa penilaian menggunakan pujian verbal maupun perilaku, jumlah bintang, benda kesukaan anak, dan lain-lain. Pemberian reward juga dapat digunakan orang tua di rumah sebagai imbalan bagi perilaku atau pencapaian anak, sehingga anak akan lebih termotivasi dalam melakukan kegiatan belajar di rumah.

Pembagian Waktu Orang Tua Antara Pekerjaannya dan Mendampingi Anak dalam Belajar Orang tua sebagai pendamping dan motivator dalam kegiatan anak belajar dari rumah secara daring sangat berperan penting selama masa pandemi Covid-19. Adanya kegiatan belajar dari rumah, tentu saja menjadi sebuah tantangan baru bagi orang tua. Salah satu tantangan yang harus dihadapi oleh orang tua yaitu pembagian waktu. Orang tua harus membagi waktu antara mendampingi anak belajar dan menyelesaikan pekerjaanya, sehingga orang tua harus membagi waktunya sebaik mungkin. Berikut ini yang dipaparkan beberapa orang tua dalam membagi waktu antara mendampingi anak belajar dan menyelesaikan pekerjaannya.

...saya mendampingi anak melakukan kegiatan belajar, sebelum atau setelah perkerjaan saya selesai, menyesuaikan mood anak untuk mengerjakan tugasnya... (kutipan wawancara ibu RN)

...sebagai ibu rumah tangga, saya biasa mendampingi anak dalam belajar pada pagi maupun sore hari, tergantung keinginan mau anak belajar... (kutipan wawancara ibu LS)

... waktu saya untuk mendampingi anak belajar pada sore hari, setelah saya menyelesaikan semua pekerjaan saya... (kutipan wawancara ibu YN)

Selama masa pandemi Covid-19, orang tua yang bekerja harus meluangkan waktu untuk mendampingi dan memotivasi anak dalam kegiatan belajar. Pembagian waktu antara mendampingi anak dalam belajar dan menyelesaikan pekerjaannya haruslah seimbang dan diatur sebaik mungkin. Meskipun beberapa orang tua merasa terbebani dan merasa tertantang dengan adanya kegiatan belajar dari rumah, namun orang tua berusaha dapat membagi waktu sebisa mungkin untuk mendampingi dan memotivasi anak dalam melakukan kegiatan belajar anak. Adanya kegiatan belajar dari rumah dapat mempererat hubungan orang tua dan anak (Rohayani, 2020). Namun beberapa orang tua merasa kegiatan belajar anak di rumah menjadi beban tambahan bagi orang tua. Orang tua dapat menciptakan suasana belajar yang aman, nyaman, dan menyenangkan bagi anak, sehingga dalam suasana yang tercipta tersebut antara orang tua dan anak tidak akan merasa terbebani dengan adanya belajar dari rumah. Dampak positif dari hal tersebut yaitu orang tua menjadi mempunyai banyak waktu yang berkualitas bersama anak (Sari et al., 2020).

\section{SIMPULAN}

Tantangan yang dihadapi guru pada kegiatan Belajar Dari Rumah (BDR) adalah membuat perencanaan kegiatan pembelajaran yang menarik dengan menyesuaikan bahan kegiatan di sekitar anak. Guru stand by memantau kegiatan anak melalui whatsapp serta melakukan penilaian terhadap anak melalui video/foto yang dikirimkan oleh anak. Sedangkan orang tua harus mengetahui dan menjaga mood belajar anak, mengajak anak melakukan kegiatan belajar dengan suasana yang menyenangkan, orang tua harus bisa 
membagi waktu antara pekerjaan dan mendampingi anak belajar. Berdasarkan hasil penelitian ini, guru dan orang tua harus bekerja sama dalam pelaksanaan kegiatan BDR.

\section{UCAPAN TERIMA KASIH}

Terimakasih kepada Allah SWT yang telah melimpahkan rahmat dan hidayahNya sehingga peneliti dapat melaksanakan penelitian dan menyelesaikan artikel jurnal ini. Terimakasih kepada dosen pembimbing yang telah meluangkan waktu dalam membimbing penyusunan jurnal hingga selesai, subjek penelitian yang telah memberikan informasi kepada peneliti, serta semua pihak yang terlibat dan membantu dalam penelitian ini.

\section{DAFTAR PUSTAKA}

Ali Nugraha. (2018). Penyusunan Kurikulum Tingkat Satuan Pendidikan (Issue 021). Direktorat Pembinaan Pendidikan Anak Usia Dini.

Apriyanti, H. (2017). Pemahaman Guru Pendidikan Anak Usia Dini Terhadap Perencanaan Pembelajaran Tematik. Jurnal Obsesi: Jurnal Pendidikan Anak Usia Dini, 1(2), 111. https://doi.org/10.31004/obsesi.v1i2.22

Ayuni, D., Marini, T., Fauziddin, M., \& Pahrul, Y. (2021). Kesiapan Guru TK Menghadapi Pembelajaran Daring Masa Pandemi Covid-19. Jurnal Obsesi : Jurnal Pendidikan Anak Usia Dini, 5(1), 414-421. https:// doi.org/10.31004/obsesi.v5i1.579

Azanella, L. A. (2020, April). Apa Itu PSBB hingga Jadi Upaya Pencegahan Covid-19? Editor: Inggried Dwi Wedhaswary. Kompas.Com.

Fadillah, M. (2019). Buku Ajar Bermain E Permainan Anak Usia Dini - Google Books. Kencana; Prenada Media.

Fadlillah, M. (2014). PAUD Menciptakan Pembelajaran Menarik, Kreatif, dan Menyenangkan. Kencana.

Hakim, M. S. H. I. (2020). Implementasi Kolaborasi Orang Tua dan Guru Dalam Pelaksanaan Pembelajaran Daring pada PAUD. JIEES : Journal of Islamic Education at Elementary School, 1(1), 26-33. https://doi.org/10.47400/jiees.v1i1.8

Hasbi, M., Wahyuni, M., \& Yuliantina, I. (2020). Rencana Pelaksanaan Pembelajaran.

Hasbi, M., Wardhani, L. K., \& Widiyawati, E. (2020). Penilaian Perkembangan Anak Selama Belajar Dari Rumah. Kementerian Pendidikan dan Kebudayaan.

Hewi, L., \& Asnawati, L. (2020). Strategi Pendidik Anak Usia Dini Era Covid-19 dalam Menumbuhkan Kemampuan Berfikir Logis. Jurnal Obsesi : Jurnal Pendidikan Anak Usia Dini, 5(1), 158. https:// doi.org/10.31004/obsesi.v5i1.530

Hutami, M. S., \& Nugraheni, A. S. (2020). Metode Pembelajaran Melalui Whatsapp Group Sebagai Antisipasi Penyebaran Covid-19 pada AUD di TK ABA Kleco Kotagede. Paudia: Jurnal Penelitian Dalam Bidang Pendidikan Anak Usia Dini, 9(1), 126-130. https:/ / doi.org/https:/ / doi.org/10.26877/ paudia.v9i1.6107

Kurnia, T. (2020). Liputan6 Update 13 September 2020 26,6 Juta Kasus Covid 19 di Dunia 919 Ribu Meninggal.pdf.

Liputan6.com. https:/ / www.liputan6.com/global/read/4354938/update-13-september-266-jutakasus-covid-19-di-dunia-919-ribu-meninggal

Lee, A. (2020). Wuhan novel coronavirus (COVID-19): why global control is challenging? In Public Health (Vol. 179, pp. A1-A2). The Royal Society for Public Health. https:// doi.org/10.1016/j.puhe.2020.02.001

Lilawati, A. (2020). Peran Orang Tua dalam Mendukung Kegiatan Pembelajaran di Rumah pada Masa Pandemi. Jurnal Obsesi: Jurnal Pendidikan Anak Usia Dini, 5(1), 549. https:// doi.org/10.31004/obsesi.v5i1.630

Mamun, M. A., Chandrima, R. M., \& Griffiths, M. D. (2020). Mother and Son Suicide Pact Due to COVID-19-Related Online Learning Issues in Bangladesh: An Unusual Case Report. 
In International Journal of Mental Health and Addiction (pp. 1-4). International Journal of Mental Health and Addiction. https://doi.org/10.1007/s11469-020-00362-5

Maryani, K. (2020). Penilaian dan Pelaporan Perkembangan Anak Saat Pembelajaran di Rumah di Masa Pendemi Covid-19. Murhum, 1(2), 41-52. https://doi.org/10.37985/murhum.v1i1.4

Menteri Pendidikan dan Kebudayaan Republik Indonesia. (2020). Surat Edaran Nomor 4 Tahun 2020 Tentang Pelaksanaan Kebijakan Pendidikan Dalam Masa Darurat Penyebaran Coronavirus Disease (COVID-19). Republik Indonesia. https:// pusdiklat.kemdikbud.go.id/ surat-edaran-mendikbud-no-4-tahun-2020tentang-pelaksanaan-kebijakan- pendidikan-dalam-masa-darurat-penyebarancorona-virus-disease-covid-1-9/

Nugraha, A., Ritayani, U., Siantiyani, Y., \& Maryati, S. (2018a). Pedoman Pengelolaan Pembelajaran Pendidikan Anak Usia Dini. Direktorat Pembinaan Pendidikan Anak Usia Dini, 2, 50. https:// doi.org/10.30651/didaktis.v18i3.1849

Nugraha, A., Ritayani, U., Siantiyani, Y., \& Maryati, S. (2018b). Pedoman Pengelolaan Pembelajaran Pendidikan Anak Usia Dini. Direktorat Pembinaan Pendidikan Anak Usia Dini, 2(021), 50.

Pebriana, P. H. (2017). Analisis Penggunaan Gadget terhadap Kemampuan Interaksi Sosial pada Anak Usia Dini. Jurnal Obsesi: Jurnal Pendidikan Anak Usia Dini, 1(1), 1. https://doi.org/10.31004/obsesi.v1i1.26

Pendidikan, K., Kebudayaan, D. A. N., \& Indonesia, R. (2020). Pentingnya Bermain Bagi Anak. $1-32$.

Puspitasari, R. (2016). Pengaruh Pemberian Hadiah (Reward) terhadap Kemandirian Belajar Anak di TK Tunas Muda Karas Kabupaten Magetan Ta 2015/2016. Seminar Nasional Ilmu Pendidikan UNS 2015 • 2015, November 2015, 53-55.

Raco, J. (2018). Metode penelitian kualitatif: jenis, karakteristik dan keunggulannya. https://doi.org/10.31219/osf.io/mfzuj

Rohayani, F. (2020). Menjawab Problematika Yang Dihadapi Anak Usia Dini di Masa. Qawwam: Journal For Gender Mainstreaming, 14(1), 29-50. https://doi.org/10.20414/Qawwam.v14i1.2310

Rozana, S., Wulan, D. S. A., \& Hayati, R. (2020). Pengembangan Kogntif Anak Usia Dini (Teori dan Praktik). Edu Publisher.

Sari, D. A., Mutmainah, R. N., Yulianingsih, I., Tarihoran, T. A., \& Bahfen, M. (2020). Kesiapan Ibu Bermain Bersama Anak Selama Pandemi Covid-19, “Dirumah Saja." Jurnal Obsesi : Jurnal Pendidikan Anak Usia Dini, 5(1), 475. https://doi.org/10.31004/obsesi.v5i1.584

Satrianingrum, A. P., \& Prasetyo, I. (2020). Persepsi Guru Dampak Pandemi Covid-19 terhadap Pelaksanaan Pembelajaran Daring di PAUD. Jurnal Obsesi : Jurnal Pendidikan Anak Usia Dini, 5(1), 633. https:/ / doi.org/10.31004/obsesi.v5i1.574

Selwyn, N., Banaji, S., Hadjithoma-Garstka, C., \& Clark, W. (2011). Providing a platform for parents? Exploring the nature of parental engagement with school Learning Platforms. Journal of Computer Assisted Learning, 27(4), 314-323. https://doi.org/10.1111/j.13652729.2011.00428.x

Sujarwo. (2012). Pengembangan Media Pembelajaran Keaksaraan. Iu, 1-14.

Suryana, D. (2017). Pembelajaran Tematik Terpadu Berbasis Universitas Negeri Padang Harus dapat Memberikan Kesempatan Umum. Jurnal Pendidikan Anak Usia Dini, 6, 67-82. https://doi.org/https://doi.org/10.21009/JPUD.111.05 PEMBELAJARAN

Wardani, A., \& Ayriza, Y. (2020). Analisis Kendala Orang Tua dalam Mendampingi Anak Belajar di Rumah Pada Masa Pandemi Covid-19. Jurnal Obsesi : Jurnal Pendidikan Anak Usia Dini, 5(1), 772. https:// doi.org/10.31004/obsesi.v5i1.705

Wulandari, H., \& Purwanta, E. (2021). Pencapaian Perkembangan Anak Usia Dini di TK selama Pembelajaran Daring saat Pandemi Covid-19. Jurnal Obsesi : Jurnal Pendidikan Anak Usia Dini, 5(1), 452-462. https://doi.org/10.31004/obsesi.v5i1.626 